\title{
ŚWIĘTE 20: GRAVES OF THE CORDED WARE CULTURE
}

\begin{abstract}
Archaeological excavations at site 20, Święte, Radymno Commune, Jarosław District, were prompted by construction of the A4 motorway. Among the results the site has yielded there are two Corded Ware graves. Both of them are niche constructions datable to the younger Corded Ware phase in Małopolska. Accommodating three interments, grave 43 is particularly interesting for the re-use of its burial chamber and re-deposition of disarticulated older human remains. Grave goods within the graves are typical of the younger Corded Ware phase, with parallels found at closely located sites of the Lower San Valley and Rzeszów Foothills. The absolute date range for both graves has been determined to be ca. 2550-2400 BC.
\end{abstract}

ABSTRACT

Key words: Final Eneolithic, Corded Ware culture, south-eastern Poland, funeral rite, chronology

\footnotetext{
Teresa Dobrakowska ARCHE, Rumiankowa 57e/5, 54-512 Wrocław, Poland; arche.dobrakowska@wp.pl

** Institute of Archaeology and Ethnology, Polish Academy of Sciences, Sławkowska 17, 31-016 Kraków, Poland; wlodarczak.piotr@gmail.com
} 
Rescue excavations at site 20, Święte, Radymno Commune, Jarosław District (acc. to Polish Archaeological Record: AZP 106-84/132), were undertaken in 2011 and 2014, ahead of the construction of the A4 motorway. They were carried out by the Narnia-Arche-Archgeo consortium and led by Agnieszka Zaradzka and Mateusz Królik (2011), and Paweł Greszata (2014). The excavated area covered 5,408 sq. m and yielded remains of Eneolithic (Funnel Beaker culture) and Early Bronze Age (Mierzanowice culture) settlements, as well as traces of World War I operations. Prehistoric occupation was also evidenced by two graves attributable to the Corded Ware culture (CWC) that are the focus of this study. Some $500 \mathrm{~m}$ east of the graves, there is a CWC cemetery at site 15 , Święte, covered by a separate study [Janczewski et al. 2015].

Site 20 is located approximately $1 \mathrm{~km}$ southwest of the present village of Święte, in the Lower San Valley [mesoregion of the Sandomierz Basin: Kondracki 1998]. In that point, the river valley is $8-10 \mathrm{~km}$ in width. The site sits on an edge of the Pleistocene terrace rising approximately 12 metres above the valley floor, on a clearly defined spur created through erosion causing undercutting of river meanders. The elevation ranges from 200 to $205 \mathrm{~m}$ a.s.l.

CWC graves are located in the western part of the excavated area that hosts numerous Early Bronze features (according to the ceramic evidence, the dating can

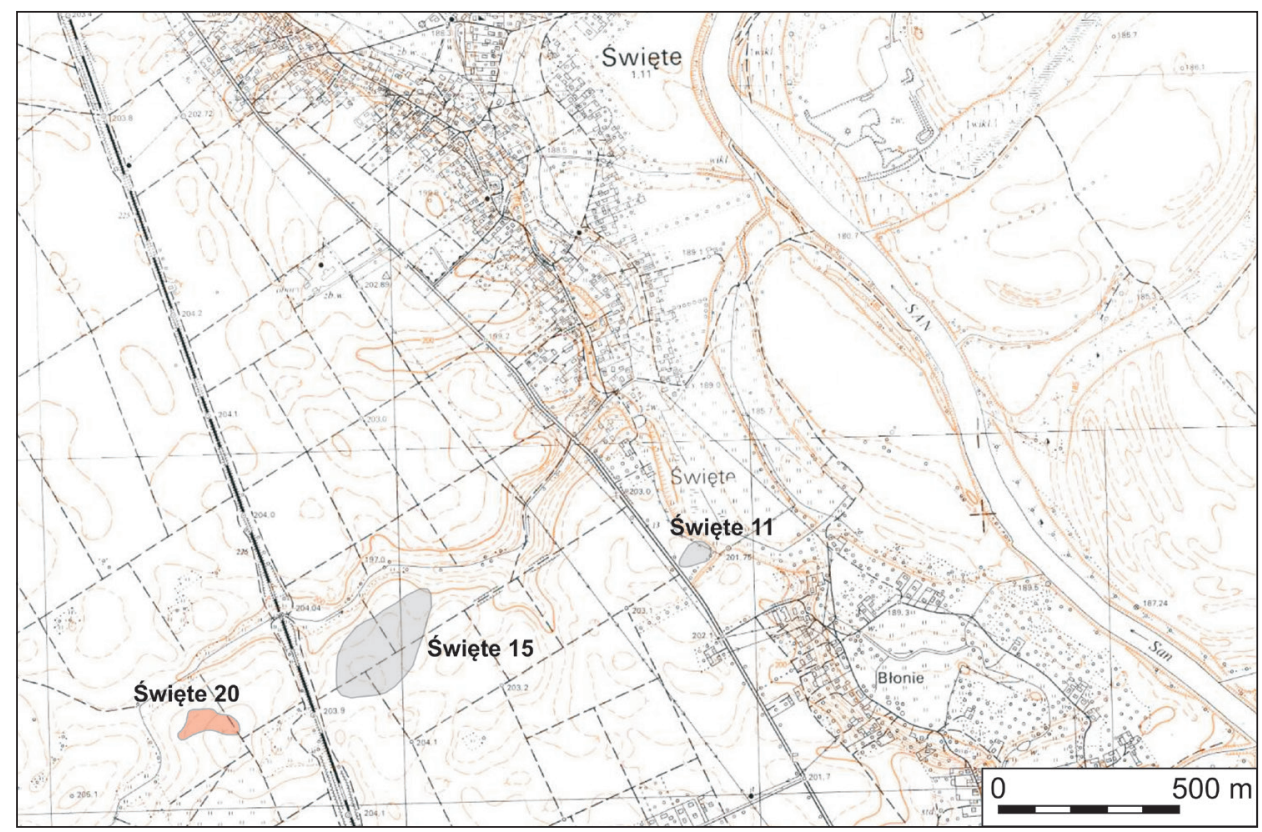

Fig. 1. Location of site 20 in Święte, Radymno Commune, Jarosław District 


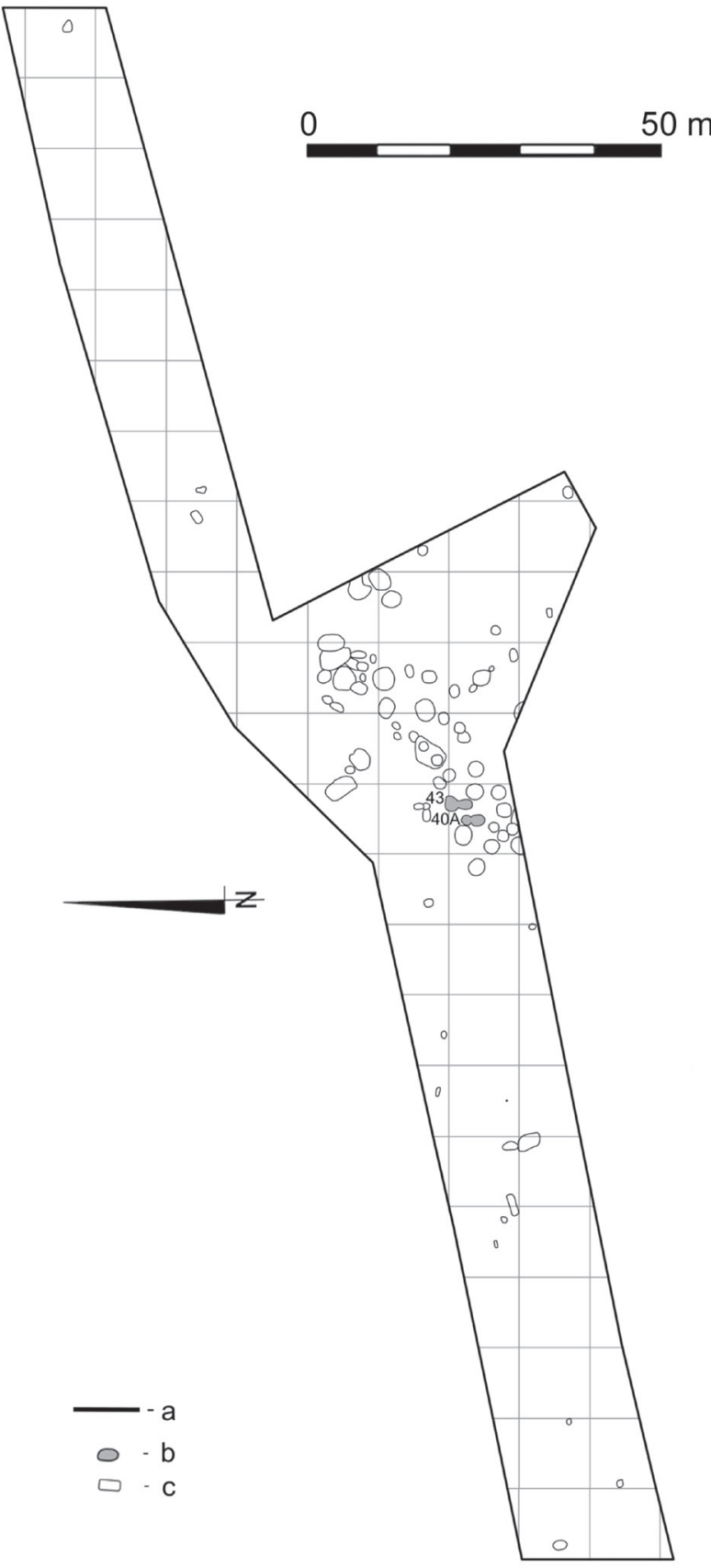

Fig. 2. Święte, site 20. Plan of area under research: a - limit of excavated area, b-CWC graves, c - Neolithic and Early Bronze Age settlement pits 
be narrowed down to the turn of the early to the late phase of the Mierzanowice culture, i.e. turn of the $3 \mathrm{rd}$ and $2 \mathrm{nd}$ millennia $\mathrm{BC}$ ). The distance between the graves is short, being approximately 2 metres. Structural properties of the graves were not properly identified during the excavations. The failure was due to difficulties in interpreting the stratigraphy, poor preservation of the features, occupational intensity in other periods as well as excavation methods applied.

1. DESCRIPTION OF THE GRAVES

\section{Grave 40A}

\begin{tabular}{|c|c|c|c|}
\hline Dating & \multicolumn{3}{|c|}{ Poz-90777: 3950 \pm 35 BC; 2563-2350 BC } \\
\hline \multirow[t]{2}{*}{ Construction type } & \multirow[t]{2}{*}{ niszowa } & Number of burials & 1 \\
\hline & & Sex & Male $^{2}$ \\
\hline \multirow{2}{*}{$\begin{array}{l}\text { Dimensions of niche } \\
\text { (m) }\end{array}$} & \multirow[t]{2}{*}{$1,9 \times 1,5$} & Age & $7-9$ years \\
\hline & & Orientation & NW-SE \\
\hline Depth (m) & 0.7 & Deviation & \\
\hline \multirow[t]{3}{*}{ Niche orientation } & \multirow[t]{3}{*}{$\mathrm{N}-\mathrm{S}$} & $\begin{array}{l}\text { Placement of head/ } \\
\text { body/lower limbs }\end{array}$ & $\mathrm{R} / \mathrm{R} / \mathrm{R}$ \\
\hline & & Lower limbs & 2 \\
\hline & & Upper limbs & ? \\
\hline
\end{tabular}

The grave forms a stratigraphic set together with pit 40 located south of it (Fig. 3: 1, B). The pit may be fairly safely considered to be an entrance shaft leading to a niche, i.e. grave 40A. If this is indeed the case, the set would be a T-shaped structure typical of the end of the Neolithic in Małopolska, with an entrance at the south and with a niche. At the bottom of the niche, there were poorly preserved remains of a child aged 7 to 9 [Szczepanek 2018] (Fig. 3: C). Its body was in a contracted position, placed transversally to the main axis of the grave. There was a small fragmentary vessel found next to the burial.

1 List of abbreviations used in tables:

Head/body/lower limbs arrangement: $\mathrm{R}$ - right side, $\mathrm{L}$ - left side, $\mathrm{U}$ - on the back.

Lower limbs: Włodarczak 2006: 58, Fig. 31: B and 60, table 13.

Upper limbs: Włodarczak 2006: 58, Fig. 31: A.

2 Sex established according to aDNA investigations conducted by Maja Krzewińska (Stockholm University). 

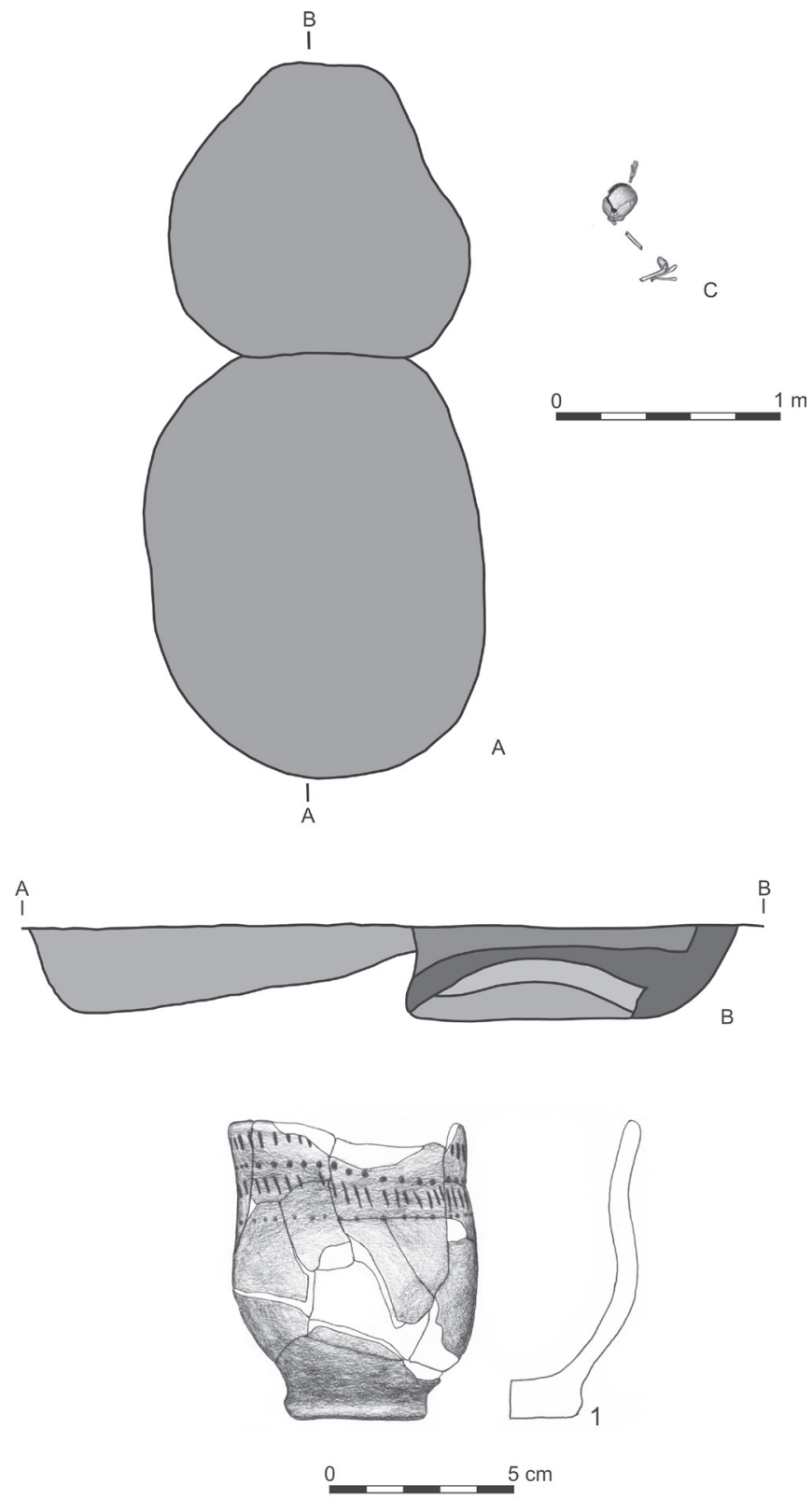

Fig. 3. Swięte, site 20. Grave 40A: A - plan at discovery level $(\mathrm{ca} .30 \mathrm{~cm}), \mathrm{B}$ - vertical profile, C - burial level, 1 - inventory. Drawing by M. Podsiadło 


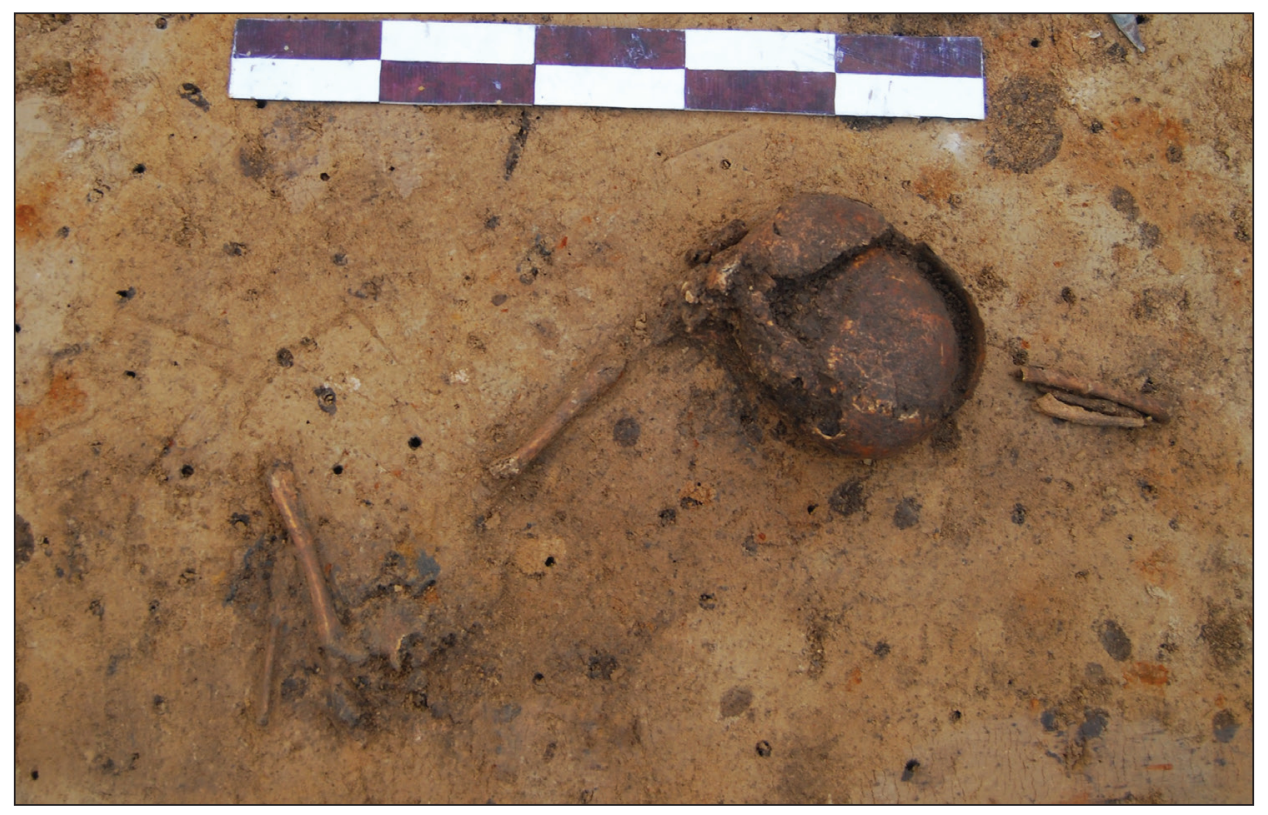

Fig. 4. Święte, site 20. Grave 40A: burial level

\section{Inventory:}

1. Beaker, S-shaped profile, straight rim, clearly defined (footed) base. The vassel is decorated with irregular diagonal notches and pricked circular patterns. Dimensions: height $-8.2 \mathrm{~cm}$; rim diameter -6.6 . cm; body diameter $-6.7 \mathrm{~cm}$; base diameter $-3.9 \mathrm{~cm}$. Fig. 3: 1 .

\section{Grave 43}

\begin{tabular}{|c|c|c|c|}
\hline Dating & \multicolumn{3}{|c|}{ Poz-90777: 3950 \pm 35 BC; 2563-2350 BC (skeleton 1) } \\
\hline \multirow[t]{2}{*}{ Construction type } & \multirow[t]{2}{*}{ niche } & Number of burials & 3 \\
\hline & & Sex & $\begin{array}{l}\text { 1. Male } \\
\text { 2. Female } \\
\text { 3. ? }\end{array}$ \\
\hline \multirow[t]{2}{*}{$\begin{array}{l}\text { Dimensions of niche } \\
\text { (m) }\end{array}$} & \multirow[t]{2}{*}{$2.0 \times 1.9$} & Age & $\begin{array}{l}\text { 1. } 40-45 \text { years } \\
\text { 2. } 44-55 \text { years } \\
\text { 3. } 7-8 \text { years }\end{array}$ \\
\hline & & Orientation & $\begin{array}{l}\text { 1. W-E } \\
\text { 2. - } \\
\text { 3. - }\end{array}$ \\
\hline Depth (m) & 1.1 & Deviation & $\begin{array}{l}\text { 1. } 0^{\circ} \\
\text { 2. - } \\
\text { 3. - }\end{array}$ \\
\hline
\end{tabular}




\begin{tabular}{|c|c|c|c|}
\hline \multirow[t]{3}{*}{ Niche orientation } & \multirow[t]{3}{*}{ N-S } & $\begin{array}{l}\text { Placement of head/ } \\
\text { body/lower limbs }\end{array}$ & $\begin{array}{l}\text { 1. } \mathrm{R} / \mathrm{R} / \mathrm{R} \\
2 .- \\
\text { 3. - }\end{array}$ \\
\hline & & Lower limbs & $\begin{array}{l}\text { 1. } 2 / 6 \\
2 .- \\
3 .-\end{array}$ \\
\hline & & Upper limbs & $\begin{array}{l}\text { 1. ? } \\
2 .- \\
\text { 3. }-\end{array}$ \\
\hline
\end{tabular}

A relationship between features 43 and 44, including their shape and orientation, was similar to that observed for features 40 and 40A. An entrance pit (feature 44), which was an elongated oval slightly shallower than a burial niche (feature 43; Fig. 9) located to the south, was filled with homogenous dark sediment (? intentional backfill). Material filling the niche was multi-layered (Fig. 5: B; 9), evidencing destruction of a ceiling that collapsed to the level somewhat higher that the burial depth (in the bottom of the grave, there was sediment accumulated that had entered through the entrance pit, being carried by water). On the bottom of the grave, three interments were identified (Fig. 5: C; 10). A male articulated skeleton was found in the southern part of the pit. Incomplete, disarticulated remains of an adult female and of a child, were identified in the north-western part of the grave. Grave goods were deposited next to the male burial as well as among remains of two other individuals (see section 3).

Inventory:

1. Beaker, S-shaped profile, neck decorated with three/four irregularly spaced lines of Z-twisted cord impressions of thick cord, rim with a clear lip, undefined and slightly concave base. Dimensions: height $-16.9 \mathrm{~cm}$, rim diameter $-\mathrm{ca} .10 \mathrm{~cm}$, body diameter $-13.8 \mathrm{~cm}$, base diameter $-4.2 \mathrm{~cm}$. Fig. $6: 1$.

2. Beaker, S-shaped profile, neck decorated with five/six lines of Z-twisted cord impressions, undefined and slightly concave base. Dimensions: height $15.7 \mathrm{~cm}$, rim diameter - ca. $9 \mathrm{~cm}$, body diameter $-12.7 \mathrm{~cm}$, base diameter $4.2 \mathrm{~cm}$. Fig. 6: 2.

3. Small undecorated flower-pot beaker, defined and flat base, carelessly executed, bearing finger impressions. Dimensions: height $-6.7 \mathrm{~cm}$, rim diameter $7.8 \mathrm{~cm}$, body diameter $-7.3 \mathrm{~cm}$, base diameter -3.9 . Fig 6: 3 .

4. Fragmentary beaker. Dimensions: height - ca. $13.5 \mathrm{~cm}$, rim diameter - ca. $10.5 \mathrm{~cm}$, body diameter - ca. $12.5 \mathrm{~cm}$, base diameter $-6.4 \mathrm{~cm}$. Fig. 6: 4 .

5. Large amphora. Poor preservation of the vessel prevents it from being reconstructed. Low neck decorated with at least four horizontal lines of Z-twisted cord impressions.

6. Rectangular axe made of yellow Carpathian mudstone, all faces polished, cutting edge clearly asymmetrical, but irregularly quadrilateral and convex, side faces convex. Dimensions: length $-8.3 \mathrm{~cm}$, width $-5.2 \mathrm{~cm}$ (cutting edge), width $2.5 \mathrm{~cm}$ (butt), thickness $-2.5 \mathrm{~cm}$. Fig. 6: 6 . 

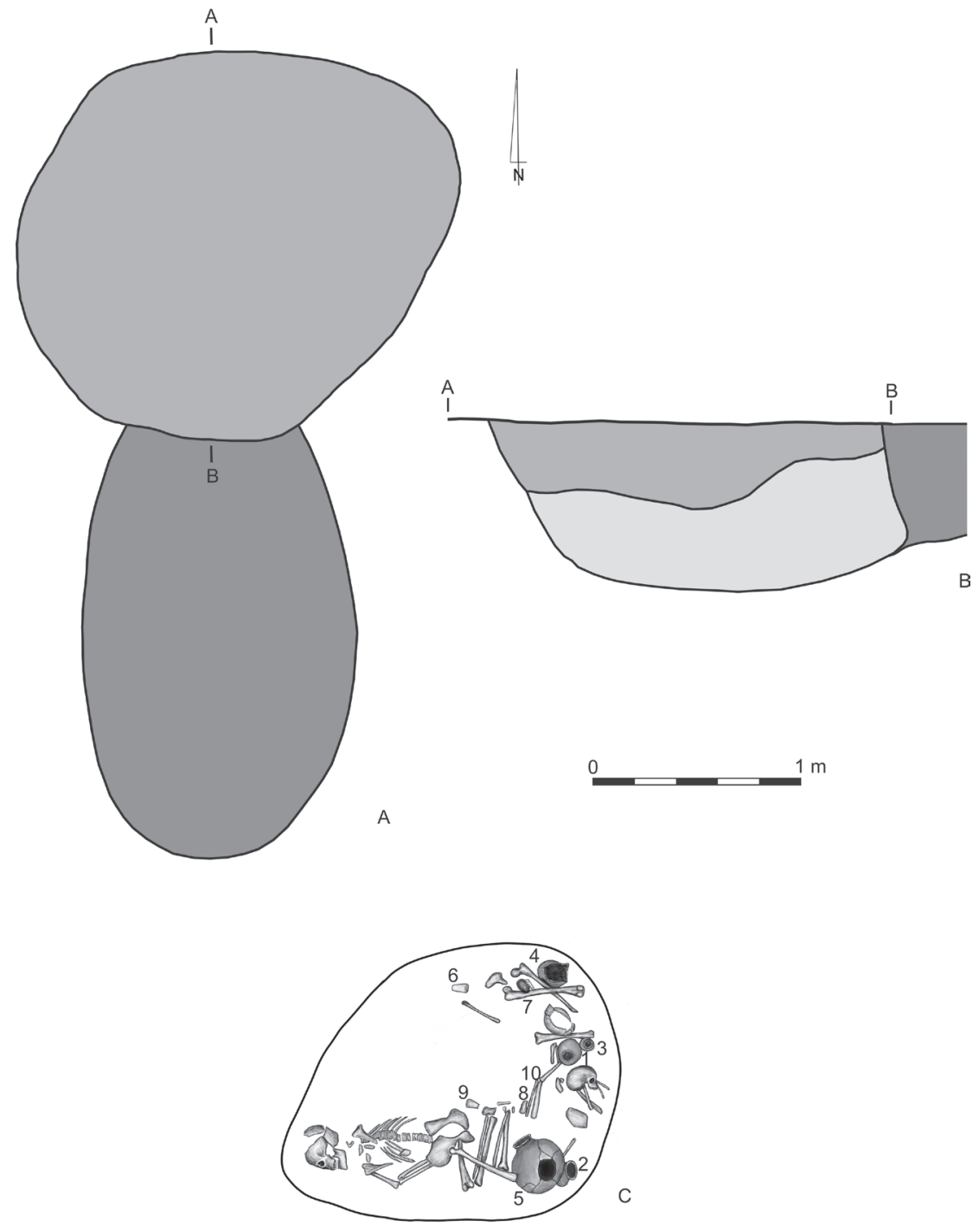

Fig. 5. Święte, site 20. Grave 43: A - plan at discovery level (ca. $30 \mathrm{~cm})$, B - vertical profile, C burial level. Drawing by M. Podsiadło

7. Rectangular axe made of beige Carpathian mudstone, all faces polished, cutting edge symmetrical, butt rectangular and flat, side faces regular and slightly convex. Dimensions: length -6.0 . $\mathrm{cm}$, width $-4.5 \mathrm{~cm}$ (cutting edge), width $-3.4 \mathrm{~cm}$ (butt), thickness $-2.3 \mathrm{~cm}$. Fig. 6: 7 .

8. Carefully finished rectangular axe made of beige Carpathian mudstone, all faces polished, cutting edge symmetrical and slightly bent, butt rectangular and 

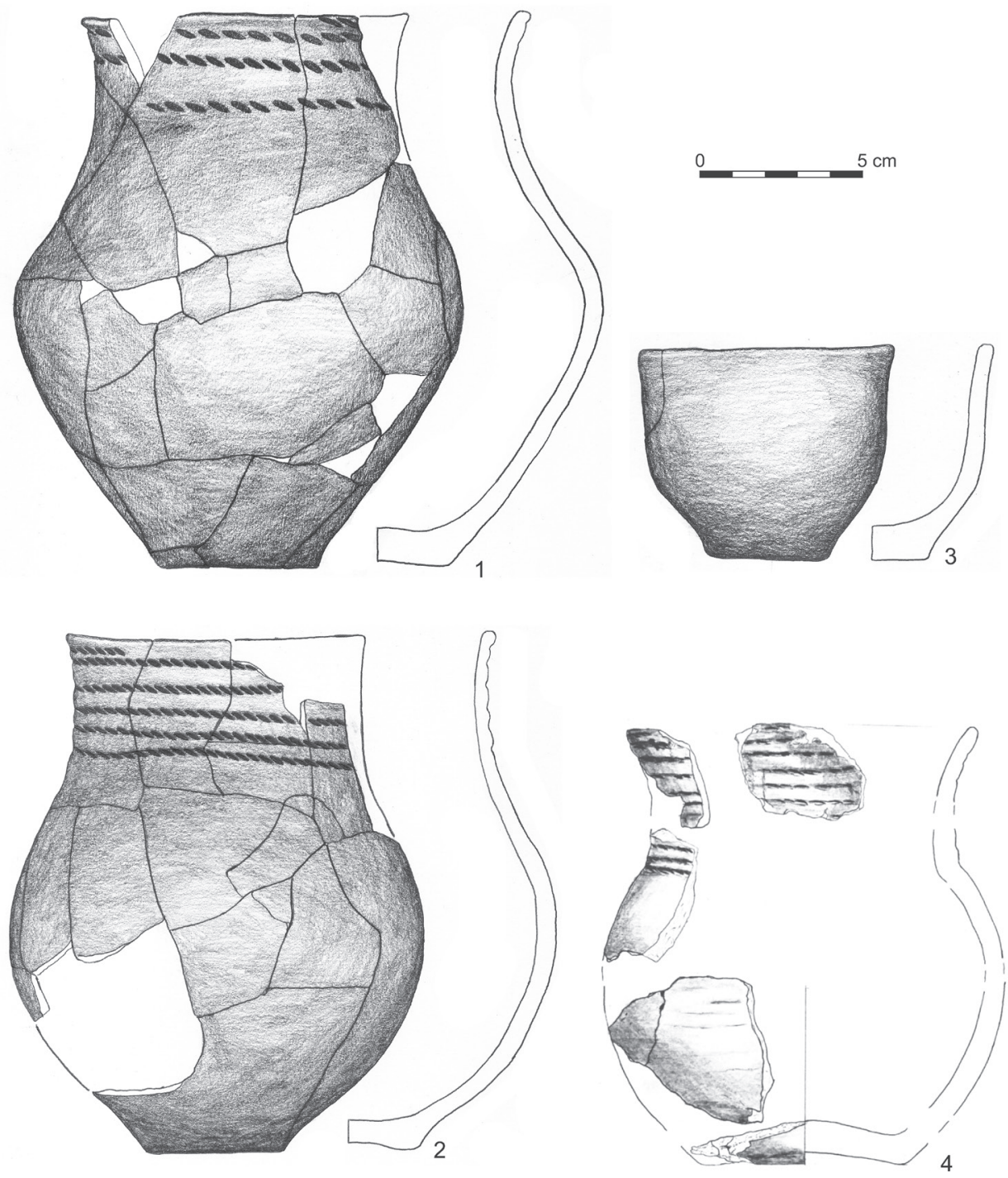

Fig. 6. Święte, site 20. Grave 43: 1-4 - inventory. Drawing by M. Podsiadło, E. Włodarczak

convex, sides regular and flat. Dimensions: length -9.0 . cm, width $-5.2 \mathrm{~cm}$ (cutting edge), width $-3.4 \mathrm{~cm}$ (butt), thickness $-2.3 \mathrm{~cm}$. Fig. $6: 7$.

9. Bifacial axe made of Volhynia flint, polished at cutting edge, side edges and thinned butt, polishing traces present also on other parts of main faces are evidence 

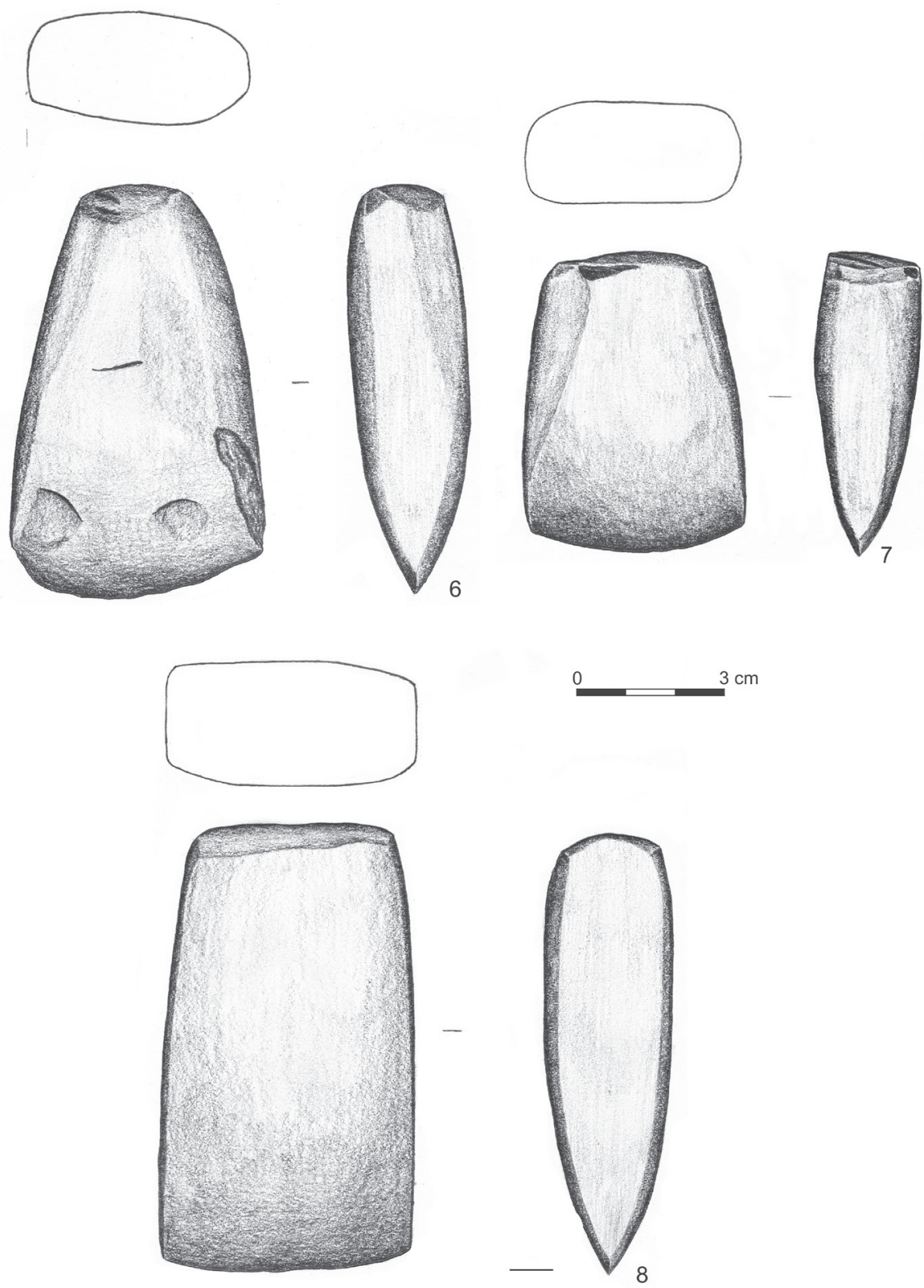

Fig. 7. Święte, site 20. Grave 43: 6-8 - inventory. Drawing by A. Dziedzic, M. Podsiadło

of an original form that was subsequently shortened and thinned, cutting edge symmetrical and curved, edges straight and formed by bifacial flaking on main faces. 

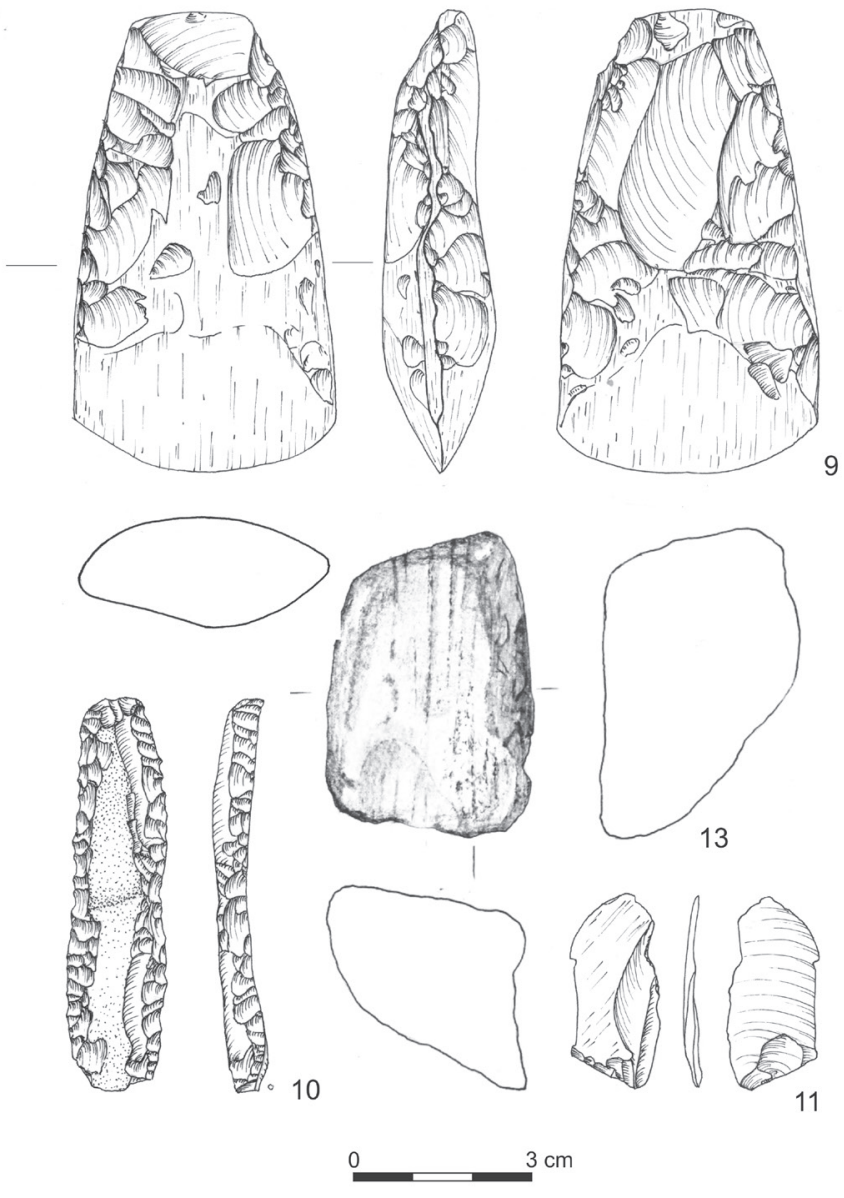

Fig. 8. Święte, site 20. Grave 43: 9-13 - inventory. Drawing by A. Dziedzic, E. Włodarczak

Dimensions: length $-7.7 \mathrm{~cm}$, width $-4.5 \mathrm{~cm}$ (cutting edge), width $-2.1 \mathrm{~cm}$ (butt), thickness $-1.9 \mathrm{~cm}$. Fig. 7: 9 .

10. Strike-a-light/retoucher on regular Volhynia flint blade, retouched regularly steeply and semi-steeply along the entire length of both sides; large fragment of natural cortical face on negative. Dimensions: 66 x 16 x 6 mm. Fig. 7: 10 .

11. Scaled piece of Volhynia flint, large fragment of polished cutting edge area (from axe) on negative. Dimensions: 33 x 14 x 2 mm. Fig. 7: 11 .

12. Scaled piece of Volhynia flint, large fragment of polished cutting edge area (from axe) on negative. Dimensions: $28 \times 12 \times 2 \mathrm{~mm}$.

13. Whetstone of medium-grained Carpathian sandstone. Dimensions: 62 x 44 x $31 \mathrm{~mm}$. Fig. 7: 13 . 


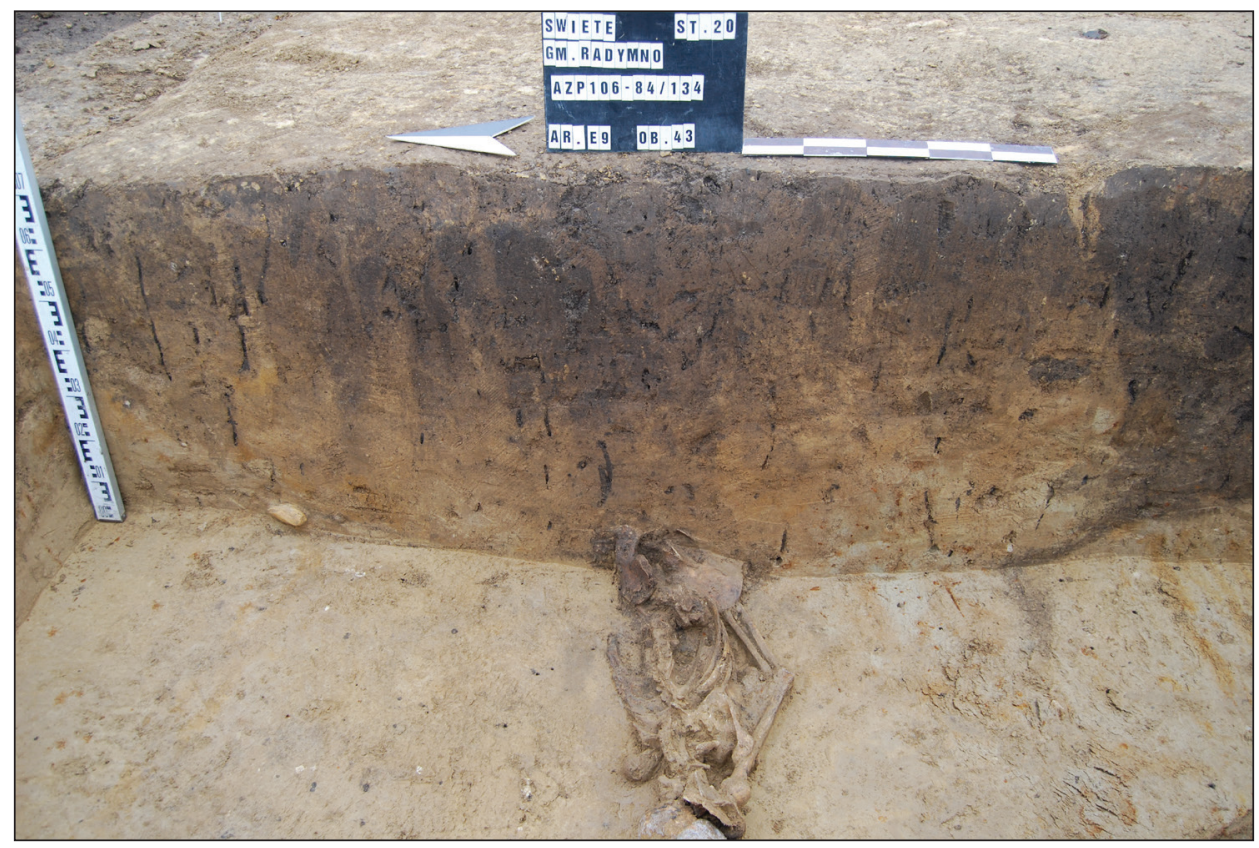

Fig. 9. Święte, site 20. Grave 43: niche profile

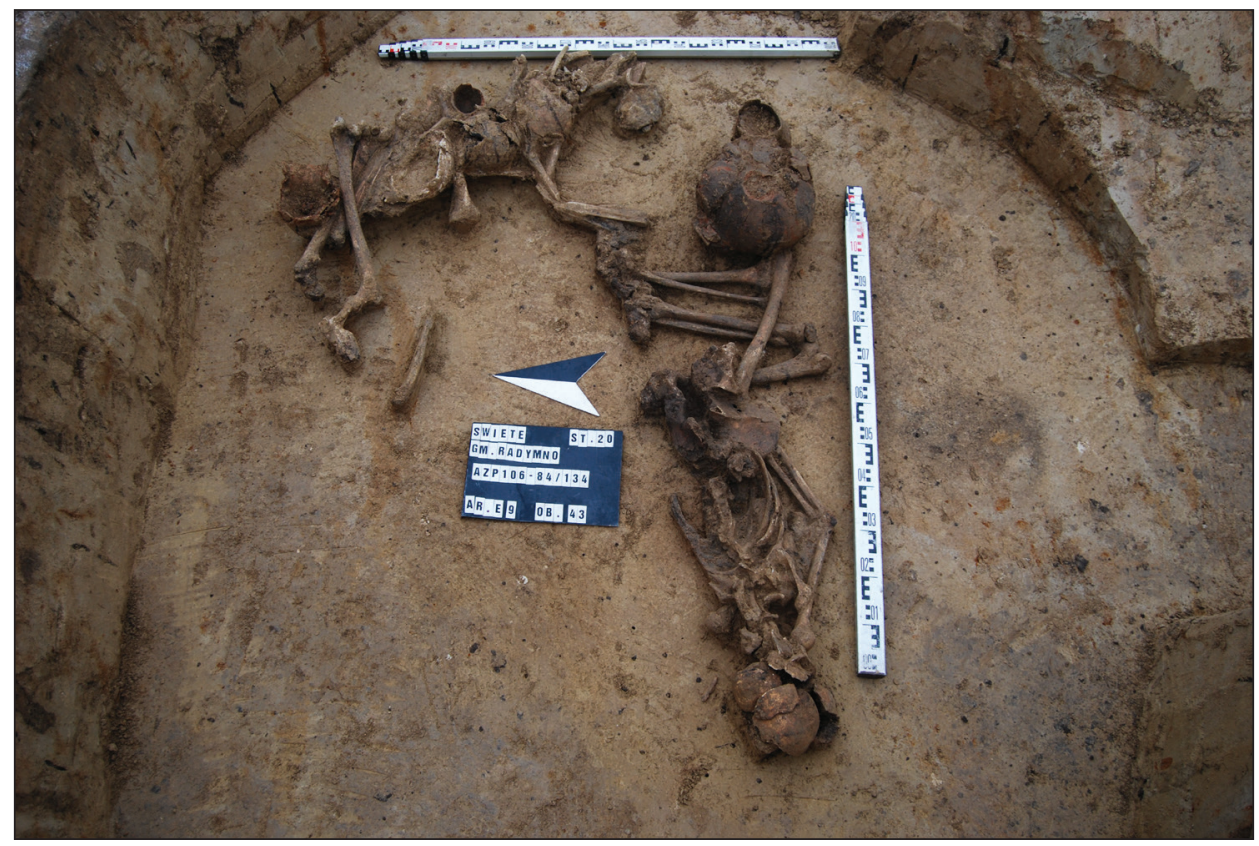

Fig. 10. Święte, site 20. Grave 43: burial level 


\begin{tabular}{|c|c|c|c|c|c|c|c|c|}
\hline $\begin{array}{l}\frac{0}{0} \\
- \\
-\end{array}$ & 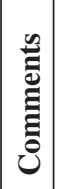 & & & & 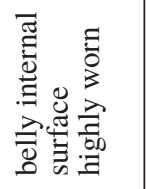 & & & \\
\hline & 离 & & 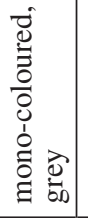 & 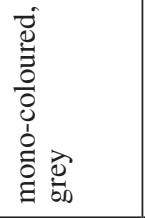 & 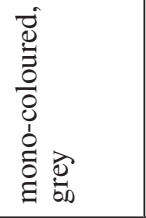 & 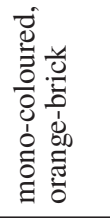 & 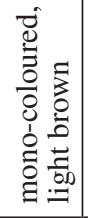 & 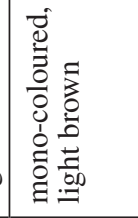 \\
\hline & & $\stackrel{\tilde{N}}{\circ}$ & 1 & $\begin{array}{l}\Xi \\
\stackrel{\Xi}{v} \\
\mathrm{v}\end{array}$ & 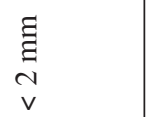 & 1 & 1 & $\begin{array}{l}E \\
\text { g } \\
n \\
v\end{array}$ \\
\hline & & 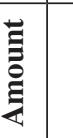 & 1 & $\stackrel{\varrho}{\Xi}$ & 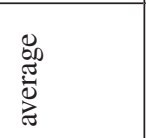 & 1 & 1 & 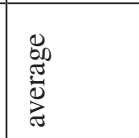 \\
\hline & : & 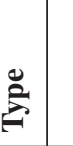 & 1 & 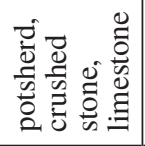 & 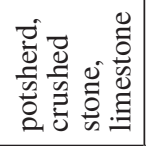 & 1 & 1 & 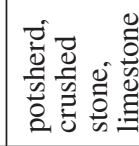 \\
\hline & : & 氧 & 离 & 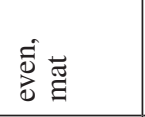 & 离 节 & $\begin{array}{l}\text { 节 } \\
\stackrel{\Xi}{\Xi} \\
\Xi\end{array}$ & 离 & 咅 $\tilde{\Xi}$ \\
\hline & 䎡 & 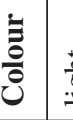 & 葛。 & 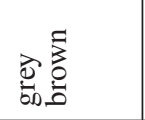 & 突 & 总言 & 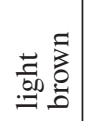 & 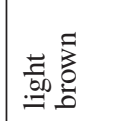 \\
\hline $\begin{array}{l}0 \\
\stackrel{0}{\pi} \\
0 \\
0 \\
0\end{array}$ & 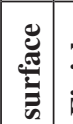 & 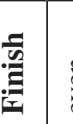 & $\dot{\bar{D}} \overrightarrow{\mathrm{J}} \overrightarrow{\mathrm{g}}$ & 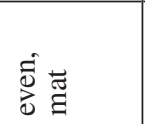 & 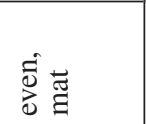 & $\begin{array}{l}\text { 苛 } \\
\stackrel{\Xi}{\Xi} \\
\Xi\end{array}$ & 离 $\vec{g}$ & 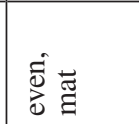 \\
\hline $\begin{array}{l}S \\
0 \\
E \\
0 \\
0 \\
0\end{array}$ & 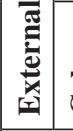 & : & 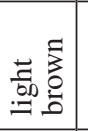 & है & 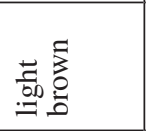 & 营唇 & 总詰 & 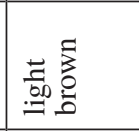 \\
\hline $\begin{array}{l}\frac{\pi}{3} \\
.0 \\
\frac{0}{E} \\
\frac{\pi}{00} \\
0 \\
0\end{array}$ & 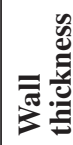 & & $\begin{array}{l}0 \\
\stackrel{0}{0} \\
1 \\
\qquad \\
0\end{array}$ & $n$ & $\tilde{n}$ & $\tilde{0}$ & $\begin{array}{l}0 \\
\dot{1} \\
1 \\
0 \\
0\end{array}$ & $\stackrel{0}{\circ}$ \\
\hline $\begin{array}{l}\overline{0} \\
\overline{\widehat{a}} \\
\frac{0}{0} \\
\overline{0}\end{array}$ & 豙 & & $\ddot{m}$ & $\ddot{\theta}$ & $\ddot{\theta}$ & $\stackrel{m}{6}$ & $\begin{array}{l}+ \\
\ddot{\theta}\end{array}$ & 1 \\
\hline 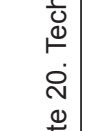 & 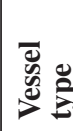 & & 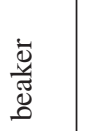 & 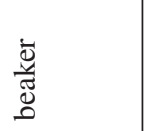 & 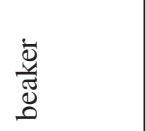 & 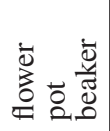 & 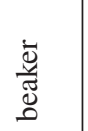 & 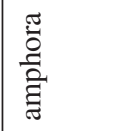 \\
\hline 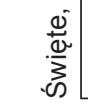 & 苞完 & & 於 & $\mathscr{q}$ & $\mathscr{q}$ & & F & $q$ \\
\hline
\end{tabular}




\section{DISCUSSION}

A relatively large excavated area (ca. 0.5 ha) of site 20 at Święte has yielded just two Corded Ware graves. These features are located in the area that also left scarce settlement traces of the Funnel Beaker culture and somewhat more relics of a settlement datable to the end of the early/beginning of the late phase of Mierzanowice culture. With no results of absolute dating available, and relying solely on a comparative typological analysis, we can conclude that both the older (ca. 3500 BC) occupational episode and the younger (ca. 2000 BC) occupational episode were separated from the CWC graves by long hiatuses of ca. 1000 and 500 years, respectively. However, there is no clearly identifiable relationship between the Final Eneolithic features and Funnel Beaker settlement pits. On the other hand, pits attributable to the Mierzanowice culture evocatively surround the CWC graves (Fig. 2). The pits are densely concentrated and, as such, are typical of the settlement pattern of the first half of the 2nd millennium BC [Kadrow 1991: 84; Włodarczak 2017: 59]. It is not clear whether this specific location of the graves is intentional or purely accidental.

No traces of any above-ground funeral structures, such as Middle Eneolithic tombs or Final Eneolithic barrows, have been identified. Therefore, the CWC graves most likely make up an entire assemblage of a small group of two flat niche structures. Most probably, both graves are approximately of the same period as indicated by their similar construction concept, orientation and proximate location. Identical radiocarbon date ranges obtained for bones of the individuals buried in each of the graves also support this view. The CWC graves are, therefore, included within a vast sacralised zone situated high above the San valley. Such zones, which are somewhat better understood now through extensive research accompanying investment projects, are typical of the younger CWC phase in Małopolska. Distances between particular small concentrations of niche graves vary between several dozen and several hundred metres (good example: site 5 at Modlnica in the Kraków region) [Włodarczak et al. 2011: 307-312]. The concentrations are sometimes not connected with above-ground structures of barrows or megalithic tombs. The zone of site 20 is likely to include site 15 at Święte, which is approximately 500 metres east, and perhaps also site 11 located further away (Fig. 1).

From the perspective of research into the organisation of CWC cemeteries in Małopolska, essential are the results of aDNA testing on the individuals from the graves under discussion ${ }^{3}$. The results show a close consanguineous relationship between the male from feature 43 (father) and the child from feature 40A (son),

\footnotetext{
${ }^{3}$ The tests have been performed by the aDNA laboratory in Stockholm, with their results being prepared for publication.
} 
thereby confirming the supposition about the family nature of small concentrations of niche graves [Kempisty 1978: 267-268; Włodarczak 2006: 48].

Both our graves are niche structures typical of the younger CWC phase in Małopolska. As far as grave 40A is concerned, the niche was accessed through the entrance with a steep threshold of several dozen centimetres in height, similar to thresholds identified within features attributable to the Kraków-Sandomierz group. On the other hand, constructional solutions incorporated in grave 43, such as the deep shaft with its bottom almost at the same level as the bottom of the niche, are typical of the Subcarpathian region. A slightly oblique (and probably short) dromos is nearly horizontal, sloping gently. This grave type is also attested at sites 11 and 15 at Święte, as well in cemeteries of the Rzeszów Foothills.

The orientation of structural elements of both graves is striking, such as the entrance located at the south. While south-facing entrances are rarely attested in western Małopolska, they are more often reported for cemeteries of the Rzeszów Foothills (sites at Mirocin and Szczytna) and Lower San Valley (sites 11 and 15 at Święte). The same orientation is also present at cemeteries of the Złota culture [Krzak 1976: 164; Włodarczak 2008: 566]. Quite long entrance pits are yet another characteristic trait of these discussed features. At the discovery level, their irregular shapes were hardly discernible against a top layer of brown loess (Fig. 2). Most probably, the pits were rounded-corner rectangles.

Grave 43 attests to a funeral practice, whereby the articulated remains of one individual are accompanied by the remains of two other individuals, mixed and concentrated in the eastern part of the niche. The mixed bones might have been redeposited from elsewhere or moved within the grave upon a successive interment. Ascertained by the anthropological analysis [Dąbrowski 2012; Szczepanek 2018], the fact that the secondarily mixed remains are incomplete is perhaps meaningful here as it suggests that the bones were moved from another location, although the possibility cannot be ruled out that some portion of the older burial within the grave was removed during the secondary ceremony. Grave 43 illustrates, therefore, a complication in the ritual that consists in various funerary treatments of corpses: articulated interment of most of the corpses and dismembering, and relocation of the remaining ones. This practice most probably ensued from more than one phase of use of burial chambers - as was the case for many features attributable to the Globular Amphorae and Złota cultures. Owing to several discoveries of recent years, this ritual practice in the CWC of Małopolska is better documented now. Most graves containing secondary burials have been reported for eastern regions: Carpathian region and Sokal Ridge. As far as the former is concerned, a similar rite can be seen in grave 408 from the nearby site 15 at Swięte [Janczewski et al. 2018: Fig. 16: A; 18], as well as burials from the Rzeszów Foothills: burial no. 220 from site 5 at Szczytna [Hozer et al. 2017: 19-28] and burial no. 360 from site 27 at Mirocin [Machnik et al. 2019]. On the Sokal Ridge, a similar burial type has been identified in grave 1 within barrow 1 at Hubinek [Machnik et al. 2009: 21-27]. The 
rite discussed here is based on the example from grave 43 and is therefore, most likely linked with the survival of the Late Eneolithic tradition (Globular Amphorae and Złota cultures) in ritual practices of Final Eneolithic communities.

The grave goods in grave 43 included: five vessels (amphora, three large beakers and small 'flower-pot' beaker), four axes, a blade tool and two flint scaled pieces). The items were intended for three individuals. Based on how the goods were arranged within the grave, the following may be fairly likely considered to be associated with the articulated burial of the adult male: large amphora (Fig 5: no. 5), beaker (no. 2), carefully finished mudstone axe (no. 8), bifacial flint axe (no. 9), blade tool (no. 10) and two scaled pieces (nos. 11 and 12). Accompanying the mixed bones of two individuals (female and individual of indeterminate sex at the age of juvenis), there were two axes and three beakers. They, however, cannot be specifically assigned to any of the two individuals. The arrangement of the items accompanying the male burial is typical of single interments, with vessels and tools placed at lower limbs and at the back, respectively. The inclusion of two typologically different axes, i.e. thick rectangular one (type: GS) and flat bifacial one (type: BA), among the grave goods is unique to adult male burials of Małopolska [Budziszewski, Włodarczak 2011: 63]. The largest number of such depositions is attested for the area occupied by the Kraków-Sandomierz group [Włodarczak 2006: 27). It is also the flint-blade strike-a-light that is only found accompanying adult male burials with grave goods including rich and diversified ranges of tools (Szczytna, site 6, grave 4: Hozer et al. 2017: 45, Fig. 25: 15].

The spatial arrangement of the goods in grave 43 is an indication that the grave goods were individually chosen for every interment in a collective grave. Specific items were assigned to particular individuals and placed in the same manner as they would have been in graves containing a single burial. A similar practice is attested also in other features from Małopolska, containing two or more burials.

Primary ceramic objects among the grave goods were three S-profiled beakers decorated solely with horizontal Z-twisted cord impressions. These ceramic forms are specific to the entire region of Jarosław: they have been found dominant also at sites 11 and 15 at Święte, and attested at the nearby site 7 at Skołoszów (grave no. 1238) [Rybicka et al. 2012]. Stylistically, the vessels can be described as medium sized, with vertical or funnel-shaped neck, spherical or biconical body, undelineated transition from belly to neck, and lacking any complex ornamentation patterns. Such vessel type prevails in the eastern part of Małopolska (Sokal Ridge, Roztocze, Subcarpathia) and the upper Dniester basin.

Vessels nos. 1 and 2 are technologically similar (Table 1), with their pastes containing crushed stone or an additive that is rarely attested for the Subcarpathian zone. A similar additive was also used for the amphora [Rauba-Bukowska 2018: Table 2]. A different production technique was employed for two other vessels, i.e. uni- (no. 3) and bipartite (no. 4) beakers. They contain no additive and their fabrics are brick-red and light brown. They are poorly finished and give the impression 
of having been made ad hoc, perhaps for funeral ritual purposes. In Małopolska, this technological variety is seen not only in collective burials (where such technological variety may be linked to a larger number of interred individuals), but also in single burials containing a larger number of vessels. This is an indication that forms of various provenance were selected as grave goods, and that vessels could be produced ad hoc for funerary purposes. Such ad hoc or primitive production technique was frequently used for small unipartite forms such as beakers, bowls or 'miniature vessels', as it is the case for grave 43.

The unipartite beaker belongs to sub-type VID that is rarely attested at CWC cemeteries in Małopolska (Pałecznica, grave 7; Żerniki Górne, grave 123) [Liguzińska-Kruk 1989: 123, Fig. 10: c; Kempisty, Włodarczak 2000: 72, Fig. 47: 3]. The ad hoc nature of the production process makes the form not particularly valuable for diagnostic purposes. Despite this reservation, in an attempt to precisely determine the provenance of the form, attention should be paid to similarities between the beaker at issue and the Globular Amphorae vessels as well as small 'mugs' from the North Black Sea region present among grave goods from the Eneolithic until the Middle Bronze Age ${ }^{4}$. What differs unipartite vessels from Małopolska from their counterparts from other regions is that the former have straight walls 'flower-pot'. Moreover, in Małopolska, these vessels are present among grave goods either as items accompanying a child burial, or as an addition to a large vessel in a grave of an adult individual. The beaker found along with the female and child remains in grave 43 fulfils both criteria.

Although the large amphora found in grave 43 cannot be reconstructed, its preserved fragments suggest that it belongs to type II [Machnik 1966; Włodarczak 2006], having four handles attached symmetrically at the top end of the body and the short funnel-shaped neck decorated with horizontal cord impressions. Such amphorae were characteristic elements of grave goods across Małopolska. While they can be primarily found within niche graves, they are rarely seen among objects accompanying central barrow burials. As such, the amphorae are of chronological value, belonging to younger CWC phases. Forms similar in size to the vessel from grave 43 are usually found within male grave goods, accompanied by bipartite beakers.

The set of four axes is a specific component of grave goods within grave 43, with three axes made of mudstone and one made of Volhynia flint. Tools made of non-silicate rock are characteristic elements of Subcarpathian grave inventories [Jarosz 2017: 27, Fig. 3]. They are also present at settlement sites located in the south-western part of the Sandomierz Basin, and linked to the Final Eneolithic and Early Bronze Age [Jarosz et al. 2010]. However, in Polish eastern Subcarpathia (Dynów Foothills and Przemyśl Foothills, Rzeszów Foothills, Lower San Valley), there are almost exclusively found in funeral contexts. A technological difference between axes made of Carpathian rock and objects made of other raw materials is

\footnotetext{
${ }^{4}$ See for Yamnaya culture: Ivanova 2013: Fig. 3.40-3.41.
} 
clear, with the former having been made in various production cycles of rectangular tools (with full processing or adapting an initial form of an objective piece). Forms such as these show a wide variety as concretions/rubble of various specifications were adapted for production purposes. They were polished along the entire length of all faces. Side faces were either flat and clearly separated from the main faces by straight edges, or convex (axes were then 'cylindrical' in cross-section as were older tools of the Neolithic Danubian cultures). The grave goods within grave 43 included both types of tools. Moreover, among axes made of Carpathian rock, there were two most characteristic types: /1/ robust, equivalent to flint forms of type G ('thick', e.g. Fig. 7: 8); and /2/ short, wide cutting edges, less robust than former, finding not many parallels among flint axes of Małopolska (Fig. 7: 7). These differences in proportions and metric properties resulted in various methods employed for mounting. Thick forms had simple, robust hafting, while finer and shorter cutting edges had lighter knee hafts.

In terms of its form, the bifacial axe made of Volhynia flint (Fig. 8: 9) is typical of tools made of eastern raw materials originating outside of Małopolska. Similar bifacial axes have been also discovered at site 11 at Święte (graves 814 and 1290D) [Olszewski, Włodarczak 2018: Fig. 11: 3; 34: 5], as well as at Szczytna and Mirocin, Rzeszów Foothills [Hozer et al. 2017: 18, Fig. 8: 12; 27, Fig. 13: 17; 46, Fig. 26: 17; 60, Fig. 35: 10; Machnik et al. 2019: 24, Fig. 9: 9, 10]. They were also present in CWC graves on the Grzęda Sokalska [Libera 2009: 287]. Production of Volhynia-flint axes was, therefore, technologically diversified, including both twoand quadrilateral forms. This may be indicative of both chronological differences, and various groups of axe makers.

The bifacial axe found in grave 43 is valuable as it adds to our knowledge of how quadrilateral tools were modified using a bifacial flaking technique. It also evidences a chronological order of changes in production carried out by Volhyniaflint users, although a typological analysis of assemblages from Małopolska shows that bifacial tools emerged relatively early and were surely used simultaneously with rectangular forms. On that basis, particular core-tool production centres can be linked to different technologies. And it was not until the Early Bronze Age that bifacial forms started to dominate also in the East Świętokrzyskie Mts. and Kraków region cultural centres. What is interesting is that these changes occurring in the Final Eneolithic and Early Bronze Age did not affect the above-described production of Carpathian-rock axes that continued in their regular rectangular form as long as the late Mierzanowice occupation and the Otomani culture.

The blade tool in grave 43 has a characteristic form of a retoucher/strike-alight (provided, however, the light striking function is more likely in the CWC grave context). It is one of fundamental types of flint tools found within CWC graves in Małopolska [Budziszewski, Tunia 2000: 27; Włodarczak 2006: 32; 2008: 291, 292], usually made using regular and quite robust blades steeply or semisteeply retouched [Tunia 1999: 164: Fig. 5: c; Włodarczak 2004: 335; Jarosz et al. 
2009: 206]. Initially, such tools were identified among the artefacts of the KrakówSandomierz group. Recently, similar forms have been discovered on the Rzeszów Foothills in: grave 4, site 6, Szczytna [Hozer et al. 2017: 45, Fig. 25: 1]; grave 220, site 5, Szczytna [Hozer et al. 2017: 14, Fig. 14: 34] and grave 110, site 24, Mirocin [Machnik et al. 2019 : 49, Fig. 25: 23]. In several cases, strike-a-lights have been found together with yellow substance that is believed to be a disintegrated lump of any ferrous mineral [e.g., Budziszewski, Tunia 2000: 127, 128; Włodarczak 2004: 335]. Fire making tools were, thus, a characteristic component of adult male burials in Małopolska of the Final Eneolithic.

To sum up, as far as graves goods from grave 43 are concerned, items characteristic of the male burial are our primary focus, consisting of the pottery vessels and relatively humble set of tools (beaker + amphora; two axes: one flat and one thick; strike-a-light). Other artefacts (three beakers and two axes) are most likely associated with two other individuals interred (female and child). As its original position within the grave remains unknown, the small sandstone whetstone cannot be linked to any of the burials.

The above-described typological, stylistic and technological similarities, including specifically the relationship between our artefacts and those found on Rzeszów Foothills, Sokal Ridge, Roztocze (Lubaczów finds) or those attributable to the Kraków-Sandomierz group, convincingly link the two graves at site 20 at Święte to the beginning of younger CWC phase - around 2600-2500 BC.

Absolute dates for human bone samples from both graves at issue have been determined. Both dates are identical and, once generalised, point to the time frame of ca. 2550-2400 BC [Włodarczak 2018]. This time frame corresponds to the older age ranges determined for CWC cemeteries at sites 11 and 15, Święte. It is not unlikely that all graves at Święte, as well as the cemetery at the nearby site 7 at Skołoszów, are dated from roughly the same time period [Rybicka et al. 2017: 128, Table 2]. The determinations are similar to the results obtained for finds attributable to the younger CWC phase in other regions of Małopolska, including specifically the area occupied by the Kraków-Sandomierz group.

Belonging to the Lower San Valley group of finds, the discoveries at site 20 at Święte are a valuable impetus of research into Final Eneolithic funerary practices of the Subcarpathian zone. They strongly contribute to our picture of the newly studied settlement micro-region of the CWC or yet another cluster with numerous niche grave cemeteries in Małopolska. 


\section{REFERENCES}

Budziszewski J., Tunia K.

2000 A Grave of the Corded Ware culture arrowheads producer in Koniusza, southern Poland. Revisited. In: S. Kadrow (Ed.) A Turning of Ages. Im Wandel der Zeiten. Jubilee book dedicated to Professor Jan Machnik on His 70th anniversary, 101-135. Kraków.

Budziszewski J., Włodarczak P.

2011 Die schnurkeramischen Beile aus den kleinpolnischen Gräbern. In: H.-J. Beier, R. Einicke, E. Biermann (Eds) Dechsel, Axt, Beil \& Co - Werkzeug, Waffe, Kultgegenstand? Aktuelles aus der Neolithforschung. Varia Archaeologica 7. Beiträge zur Ur- und Frühgeschichte Mitteluropas 63, 55-64. Langenweissbach.

Dąbrowski P.

2012 Analiza antropologiczna szczątków kostnych ze stanowiska archeologicznego Święte (st. 20), gm. Radymno. In: K. Nowaczyk L. Nowaczyk (Eds) Opracowanie wyników ratowniczych badań archeologicznych na stanowisku Święte 20 (azp 106-84/132), gm. Radymno, pow. jarosławski, woj. podkarpackie [manuscript]. Warszawa.

Hozer M., Machnik J., Bajda-Wesołowska A.

2017 Groby kultury ceramiki sznurowej i domniemane kultury mierzanowickiej w Szczytnej, pow. Jarosław - źródła, analizy, wnioski. In P. Jarosz, J. Machnik (Eds) Nekropolie ludności kultury ceramiki sznurowej z III tysiąclecia przed Chr. w Szczytnej na Wysoczyźnie Kańczuckiej. Via Archaeologica Ressoviensia 12, 7-130. Rzeszów.

Ivanova S.V.

2013 Kulturno-istoricheske kontakty naseleniya Severo-Zapadnogo Prichernomoria v rannem bronzovom veke: Zapad-Vostok. Stratum plus 2(2013): 158-248.

Janczewski P., Kraus P., Wlodarczak P.

2018 Swięte 15: cemetery of the Corded Ware culture. Baltic-Pontic Studies 23: 93-139.

Jarosz P.

2017 Dispersion of siliceous raw materials for the production of axes on the Corded Ware culture sites in the Carpathian basins of the Vistula, Dniester and Tisza Rivers. Acta Archaeologica Carpathica 52: 23-37. 
Jarosz P., Tunia K., Włodarczak P.

2009 Burial mound no. 2 in Malżyce, the district of Kazimierza Wielka. Sprawozdania Archeologiczne 61: 175-231.

Jarosz P., Włodarczak E., Włodarczak P.

2010 Settlement finds of the Corded Ware Culture in the valley of the upper Vistula. Kraków Bieżanów, site 33. Acta Archaeologica Carpathica 45: 7-27.

Kadrow S.

1991 Iwanowice. Stanowisko Babia Góra, część I. Rozwój przestrzenny osady z wczesnego okresu epoki brązu. Kraków.

Kempisty A.

1978 Schytek neolitu i początek epoki brązu na Wyżynie Małopolskiej w świetle badań nad kopcami. Kraków.

Kempisty A., Włodarczak P.

2000 Cemetery of the Corded Ware culture in Żerniki Górne. Światowit Supplement Series P 5. Warsaw.

Kondracki J.

1998 Geografia regionalna Polski. Warszawa.

Krzak Z.

1976 The Złota culture. Wrocław-Warszawa-Kraków-Gdańsk.

Libera J.

2009 Materiały krzemienne z badan kurhanów kultury ceramiki sznurowej na Grzędzie Sokalskiej. In: J. Machnik, J. Bagińska, W. Koman, Neolityczne kurhany na Grzędzie Sokalskiej w świetle badan archeologicznych $w$ latach 1988-2006. Z aneksami Jerzego Libery i Lucjana Gazdy. Kraków.

\section{Liguzińska-Kruk Z.}

1989 Kurhan kultury ceramiki sznurowej w Pałecznicy, woj. Kielce. Sprawozdania Archeologiczne 40: 113-127.

Machnik J.

1966 Studia nad kulturą ceramiki sznurowej w Małopolsce. Wrocław-WarszawaKraków.

Machnik J., Bagińska J., Koman W.

2009 Neolityczne kurhany na Grzędzie Sokalskiej w świetle badan archeologicznych w latach 1988-2006. Z aneksami Jerzego Libery i Lucjana Gazdy. Kraków. 
Machnik J., Jarosz P., Mazurek M.

2019 Groby kultury ceramiki sznurowej ze stanowisk 24 i 27 w Mirocinie, pow. Przeworsk. In: P. Jarosz, J. Machnik, A. Szczepanek (Eds) Nekropolie ludności kultury ceramiki sznurowej z III tysiąclecia przed Chr.w Mirocinie na Wysoczyźnie Kańczuckiej, 7-134. Rzeszów.

Olszewski A., Włodarczak P.

2018 Święte 11: cemetery of the Corded Ware culture. Baltic-Pontic Studies 23: 7-68.

Rauba-Bukowska A.

2018 Microscopic analysis of pottery fragments from the Corded Ware culture at sites 11, 15 and 20 in Święte, Jarosław District. Baltic-Pontic Studies 23: 163-177.

Rybicka M., Głowacz M., Król D.

2017 Datowania radiowęglowe wielokulturowego cmentarzyska ze Skołoszowa, stanowisko 7, pow. jarosławski, woj. podkarpackie. In: M. Rybicka (Ed.) Wielokulturowe cmentarzysko w Skołoszowie, stanowisko 7 pow. jarosławski w kontekście osadnictwa z neolitu $i$ wczesnej epoki brąu we wschodniej części Podgórza Rzeszowskiego, 113-142. Rzeszów.

Rybicka M., Król D., Rogoziński J.

2012 Opracowanie ratowniczych badan archeologicznych na stanowisku Skołoszów 7. Tom 1 [manuscript]. Rzeszów.

Szczepanek A.

2018 Anthropological picture of the Corded Ware population of the Subcarpathian region in the light of data obtained from the sites at Święte, Jarosław District. Baltic-Pontic Studies 23: 213-228.

Tunia K.

1999 Cmentarzysko kultury ceramiki sznurowej w Lękawie, woj. świętokrzyskie. Sprawozdania Archeologiczne 51: 159-180.

Włodarczak P.

2004 Cemetery of the Corded Ware culture in Zielona, Koniusza Commune, Małopolska/Cmentarzysko kultury ceramiki sznurowej w Zielonej, gm. Koniusza. Sprawozdania Archeologiczne 56: 307-360.

2006 Kultura ceramiki sznurowej na Wyżnie Małopolskiej. Kraków.

2008 Krzemień czekoladowy w kulturze ceramiki sznurowej na Wyżynie Małopolskiej. In: W. Borkowski, J. Libera, B. Sałacińska, S. Sałaciński (Eds) Krzemień czekoladowy $w$ pradziejach. Materiaty $z$ konferencji w Orońsku, 08-10.10.2003, 277-303. Warszawa-Lublin. 
2017 Małopolska at the beginning of the Bronze Age (2000-1600 BC). In: U. Bugaj (Ed.) The Past societies. 3. 2000-500 BC. Polish lands from the first evidence of human presence to the early Middle Ages, 49-85. Warszawa.

2018 Chronometry of the Final Eneolithic cemeteries at Święte, Jarosław District, from the perspective of cultural relations among Lesser Poland, Podolia and the north-western Black Sea region. Baltic-Pontic Studies 23: 178-212.

Włodarczak P., Zastawny A., Grabowska B.

2011 Groby kultury ceramiki sznurowej i kultury mierzanowickiej ze st. 5 w Modlnicy, pow. krakowski. In: J. Kruk, A. Zastawny (Eds) Modlnica, st. 5. Od neolitu do wczesnej epoki brązu, Via Archaeologica. Źródta $z$ badań wykopaliskowych na trasie autostrady A4 w Małopolsce, 291-410. Kraków. 